\title{
Air dan Dampak Kelangkaannya Bagi Perekonomian Masyarakat Urban: Studi Pustaka Pulau Jawa
}

\author{
Ratna Indah Lestari, Rina Ramadhani, Sherawali, Ana Toni Roby Candra Yudha \\ Universitas Islam Negeri Sunan Ampel Surabaya \\ ratnaindah257@gmail.com, ramadhanirina18@gmail.com, \\ sherawali05@gmail.com, anatoniroby@uinsby.ac.id
}

\begin{tabular}{l}
\hline Article Info \\
\hline Article history: \\
Published: Dec 28,2021 \\
Page: $38-48$ \\
\hline
\end{tabular}

Keyword:

Kelangkaan, Sumber daya air, Perekonomian

masyarakat, Pulau Jawa

\begin{abstract}
Tujuan studi ini yakni untuk mengetahui dan menganalisis pengaruh sumber daya air terhadap perekonomian masyarakat urban di Pulau Jawa serta menjawab kebenaran isu kelangkaan air bersih pada tahun 2040. Hasil dari penelitian ini menunjukkan bahwa isu kelangkaan air di Pulau Jawa pada tahun 2040 di akibatkan oleh perubahan iklim, pertumbuhan penduduk, perubahan tata guna lahan dan pencemaran air. saran yang bersesuaian dengan hal ini adalah semua stakeholders diharapkan sadar dan terus mengawasi ketersediaan air bersih dengan edukasi dan sosialisasi di berbagai level profesi dan tingkat pendidikan dalam rangka untuk memperoleh kemanfaatan air yang lebih berkelanjutan.
\end{abstract}

Kata kunci : Kelangkaan, Sumber daya air, Perekonomian masyarakat, Pulau Jawa

The purpose of this study is to determine and analyze the effect of water resources on the economy of urban communities in Java and to answer the issue of clean water scarcity in 2040. The results of this study indicate that the issue of water scarcity in Java in 2040 is caused by climate change.population growth, land use change and water pollution. The suggestion in accordance with this is that all stakeholders are expected to be aware of and continue to monitor the availability of clean water by providing education and socialization at various professional and educational levels in order to obtain more sustainable use of water.

Keyword: Scarcity, Water resources, Community economy, Java Island

Copyright $(2021$ OECONOMICUS Journal of Economics

\section{Pendahuluan}

Indonesia adalah negara maritim dimana hampir seluruh wilayahnya berupa perairan, tak heran apabila Indonesia dikenal dengan negara kaya akan sumber daya alam khususnya air. Berdasarkan Laporan Kinerja Direktorat Jendral Sumber Daya Air
Kementrian PUPR tahun 2017, Indonesia memiliki ketersediaan air di Indonesia mencapai 3,9 triliun m3/tahun. Bahkan menurut organisasi Water Environment Patnership in Asia (WEPA), Indonesia berada pada posisi ke-5 sebagai negara yang memiliki potensi air di dunia sebesar $6 \%$.

\section{Editorial Office:}

Prodi Ilmu Ekonomi Fakultas Ekonomi dan Bisnis Islam, UIN Sunan Ampel Surabaya

Jl. Ahmad Yani 117 Surabaya, Jawa Timur 60237, Indonesia.

Email: oje@uinsby.ac.id 
Indonesia juga dikenal sebagai negara dengan penduduk terbanyak di dunia yang menempati posisi ke-4 pada tahun 2021 dengan jumlah penduduk 276 juta jiwa, dimana setiap penduduk memiliki keinginan memenuhi kebutuhan dasarnya seperti memanfaatkan air. Sumber daya air merupakan anugerah dari Tuhan Yang Maha Esa yang dimiliki oleh Indonesia. Sumber daya alam air ini merupakan sumber daya alam vital yang menguasai hajat hidup orang banyak. Namun ketersediaan air di Indonesia dapat dikatakan tidak merata mengingat setiap pulau di Indonesia memiliki letak geografis dan jumlah penduduk yang berbeda-beda. Seperti halnya pulau Kalimantan yang memiliki ketersediaan air sebesar 33,60\%. Namun di pulau Jawa sendiri yang notabene memiliki jumlah penduduk terbesar di Indonesia, hampir setengah dari penduduk Indonesia menduduki pulau Jawa, ketersediaan air nya hanya 4,20\% setelah Bali dan Nusa Tenggara $7,70 \%$ pada tahun 2017 .

Pada akhirnya muncul adanya isu terkait Pulau Jawa akan mengalami kelangkaan air pada tahun 2040. Krisis air tentunya akan berpengaruh terhadap kehidupan mahkluk hidup yang berada di bumi khususnya manusia. Hewan, tumbuhan, hewan memerlukan air untuk bertahan hidup. Air adalah salah satu sumber daya alam yang secara cepat menjadi sumberdaya yang makin langka dan tidak ada sumber penggantinya. Apabila ada kelangkaan air maka makhluk hidup tidak akan bertahan hidup. Dalam hal memnuhi kebutuhanya manusia membutuhkan sumber air bersih untuk di konsumsi. Permasalahan kelangkaan air ini berakar dari perolehan sumber air bersih yang memburuk dan juga ketersediaan sumber air yang menipis, menipisnya ketersediaan air bersih tersebut dipicu oleh beberapa faktor yakni perubahan iklim dan jumlah penduduk yang semakin tinggi. Oleh karena itu dalam hal ini ketersediaan air tidak seimbang dengan kebutuhan makhluk hidup akan air. Adanya penurunan jumlah dan kualitas air di tengah masyarakat, khususnya masyarakat pinggiran kota (urban) tentu perlu adanya upaya pencegahan, penanganan dan pembaharuan. Isu tentang kelangkaan air tersebut inilah yang menarik perhatian untuk dikaji secara literatur, yang pada ujungnya diharapkan memperoleh usulan ilmiah yang obyektif dan aplikatif.

\section{Kajian Pustaka}

Ulasan pada bagian tinjauan literatur terdiri dari beberapa literatur. Literatur tersebut diantaranya adalah sumber daya air, kelangkaan, dan pertumbuhan penduduk.

Sumber daya air sebagai salah satu dari kekayaan sumber daya alam Indonesia yang sangat penting keberadaannya sejajar dengan udara. Semua makhluk hidup sangat membutuhkan air untuk keberlangsungan hidupnya, tanpa air tidak akan ada kehidupan di bumi. Air dapat ditemukan beberapa bentuk sekaligus dalam kehidupan sehari-hari seperti cair (air), padat (es), dan gas (uap air). Air dikenal sebagai kebutuhan pokok dalam kehidupan sehari-hari di semua lingkup, semua tingkatan kehidupan, dan di setiap bangsa. Air memiliki manfaat untuk tubuh makhluk hidup, khususnya manusia dimana di dalam tubuh manusia 60 persennya merupakan unsur air. Air juga bermanfaat untuk memenuhi keperluan rumah tangga.

Selain itu, air juga digunakan untuk irigasi, sebagai bahan utama industri air mineral, dan bisa untuk aset rekreasi seperti kolam renang. Di bidang energi sendiri air juga dapat digunakan sebagai sumber tenaga listrik sebagai pengganti minyak bumi karena mengingat sumber daya air ini merupakan sumber daya alam yang dapat terbarukan dan energi yang dihasilkan cenderung tidak menyebabkan polusi.

Menurut Kodoati dan Sjarief (2010) Air merupakan sumber daya alam yang terbarukan dan dinamis, dimana sumber utama air yang berupa hujan akan datang sesuai dengan waktu dan musimnya 
sepanjang tahun. Indonesia sendiri termasuk negara dengan musim tropis dimana memiliki curah hujan yang tinggi. Namun pada kondisi geologis tertentu dimana proses perjalanan air tanah memerlukan waktu ribuan tahun, sehingga bila pengambilan air tanah dilakukan secara berlebihan, air akan habis.

Menurut Bonaraja Purba (2020) kelestarian kuantitas air dipengaruhi oleh beberapa faktor yaitu ketersediaan air dan pemanfaatan air. Adanya opini manusia bahwa air tidak akan pernah habis, bisa mengakibatkan sikap manusia yang tidak peduli dengan ketersediaan air khususnya air khusunya air bersih karena menganggap selalu terjadi siklus air. Manusia pun dengan kebutuhannya yang tidak terbatas akan menggunakan air dengan tidak memperhatikan kepentingan yang mendesak. Disisi lain, mereka yang berada di wilayah-wilayah yang terhitung sulit akan sumber air khususnya air bersih harus berjalan jauh dan melakukan pengorbanan untuk mendapat sumber daya.

Kelangkaan menunjukkan kondisi terbatasnya sesuatu, baik berupa kebutuhan maupun sumber daya. Kelangkaan juga diartikan sebagai kondisi di mana seseorang tidak mempunyai cukup sumber daya untuk memuaskan kebutuhannya. Kelangkaan telah lama diketahui dan dipahami sebagai pembahasan yang klasik namun memiliki dampak yang cukup besar bagi kehidupan manusia di segala sektor. Maka dari itu, kelangkaan ini lah termasuk salah satu masalah dalam ekonomi.

Kelangkaan merupakan adanya keterbatasan sumber daya (limited resources) sebagai alat pemuas kebutuhan sedangkan kebutuhan dan keinginan manusia yang tiada batas. Adanya perilaku manusia yang bersifat emosional dibanding perilaku rasionalnya, merupakan salah satu penyebab terjadinya kelangkaan.

Untuk menentukan terjadinya kelangkaan sumber daya, menurut Tietenberg (1992) ada lima kriteria yang mendasarinya antara lain : pertama, Adanya indikator fisik yang mengutarakan ketersediaan sumber daya secara fisik. Apabila secara fisik sumber daya ketersediannya berlimpah, maka dapat dikatakan bahwa sumber daya tersebut masih belum mengalami kelangkaan. Sebaliknya jika ketersediaan fisiknya sedikit, maka sumber daya tersebut dapat dikatakan langka.

Kedua, harga dari sumber daya tersebut dapat menunjukkan peningkatan permintaan akibat tersedianya stok. Apabila semakin sulit pengorbanan untuk mendapatkan sumber daya tersebut, maka semakin mahal pula harga dari sumber daya; Ketiga, adanya nilai kelangkaan marjinal (marginal scarcity rent) faktor-faktor penyebab kelangkaan harus dapat dipertimbangkan dalam analisis. Kelangkaan selanjutnya menandai biaya opportunity cost yang kemudian disebut sebagai biaya penggunaan; Keempat, Adanya biaya penemuan marjinal (marginal discovert cost) jadi jika semakin besar biaya penemuan marjinal, maka sumber daya tersebut akan semakin langka dan berlaku juga sebaliknya. Sedangkan yang Kelima, biaya ekstraksi marjinal. Jadi, apabila biaya ektraksi ini mengalami peningkatan, maka terjadi kelangkaan sumber daya alam.

Dengan adanya masalah ekonomi yaitu kelangkaan, manusia dihadapkan dengan menentukan pilihan dari berbagai alternatif yang tersedia di atas kebutuhan yang seharusnya dapat terpenuhi semua. Penelitian oleh pada penelitiannya menjelaskan bahwa kelangkaan , dalam hal ini kelangkaan air, dapat mengancam keamanan global karena adanya persaingan dari negara-negara untuk menguasai sumber daya air yang jumlahnya semakin terbatas. Kelangkaan dapat memicu konflik yang akan mengancam keamanan global. Negaranegara akan berjuang untuk mencari sumber air sebanyak-banyaknya untuk kepentingan kesejahteraan rakyatnya.

Pertumbuhan memiliki kata dasar 
yaitu "tumbuh". Dalam KBBI, arti kata "tumbuh" adalah timbul (hidup) dan bertambah besar atau sempurna. Pertumbuhan sendiri memiliki arti sebuah perubahan suatu objek, dalam hal ini bisa seputar tinggi, berat, dan volume. Pertumbuhan juga dapat diartikan sebagai perubahan secara kuantitas suatu objek.

Sedangkan dalam KBBI arti "penduduk" adalah orang atau orang-orang yang mendiami suatu tempat (kampung, negeri, pulau, dan sebagainya).

Teori pertumbuhan penduduk yang dikemukakan oleh Paul Edric dalam bukunya yang berjudul (the population bomb) bahwa dunia ini terlalu banyak manusia sehingga di dunia ini lingkungan sudah banyak yang rusak dan tercemar. Paul Edric mengkhawatirkan jika pertumbuhan penduduk terus bertambah, kerusakan dan pencemaran lingkungan yang parah akan terjadi karena banyak penduduk yang merisaukan. (Mantra:2000), semakin meningkatnya jumlah penduduk dapat menyebabkan dampak negatif khususnya terhadap ekosistem. Hal tersebut dikarenakan adanya peningkatan kebutuhan penduduk yang semakin lama, semakin bertambah.

\section{Metode Penelitian}

Jurnal ini ditulis menggunakan pendekatan kualitatif, karena permasalahan yang diangkat berhubungan dengan kehidupan manusia secara fundamental yang bergantung pada pengamatan. menyatakan bahwa pendekatan kualitatif berdasarkan fenomenologis menuntut pendekatan yang holistik, artinya menyeluruh, mendudukkan suatu kajian dalam suatu konstruksi ganda. Penulis menggunakan pendekatan fenomenologis dengan mengacu pada kenyataan yang ada serta keterkaitan masyarakat dangan permasalahan tersebut dan juga penulis ingin mengetahui kesadaran masyarakat akan adanya ketersediaan air bersih yang semakin menurun kualitasnya. Hal ini sifatnya terbatas pada suatu wilayah saja yaitu berfokus pada pulau Jawa dan sifatnya adaptif (dapat berubah-ubah) karena data yang dibandingkan adalah data berdasarkan urutan waktu.

Dilakukannya penelitian untuk berusaha menjawab kebenaran adanya isu kelangkaan air yang mungkin akan terjadi pada tahun 2040 dan faktor penyebab pulau Jawa akan mengalami kelangkaan air serta analisis dampak dari adanya kelangkaan tersebut terhadap perekonomian jika memang benar terjadi. Sehingga hasil penelitian dapat bermanfaat bagi pemerintah daerah atau pusat agar selalu memperhatikan kondisi air, kuantitas air bersih yang tersedia dan memperkirakan penggunaan maksimal air untuk kebutuhan masyarakat sendiri dan industri yang ada.

Metode analisis yang dilakukan pada jurnal ini adalah menggunakan metode analisis deskriptif kualitatif. I Made Wibartha (2006:155) berpendapat bahwa metode analisis deskriptif kualitatif merupakan menganalisis, menggambarkan dan meringkas berbagai kondisi, situasi dari data yang sudah tersedia sebelumnya.

Tujuan dari penggunaan metode analisis data sekunder ini adalah menerapkan data dari penelitian terkait isu kelangkaan air terdahulu di beberapa daerah untuk kepentingan penelitian yang sekarang dan untuk memunculkan gagasan baru. Data sekunder dalam penelitian yang kami tulis bertujuan untuk melakukan pengujian ketidakbenaran dengan bukti kebenaran, mengekspor data dari sudut pandang yang berbeda. Teknik pengumpulan data pada penelitian ini menggunakan studi literatur digunakan untuk mendapatkan data teoritis yang relevan dan mendukung pembahasan masalah ketersediaan air bersih yang sedang diangkat, khususnya di pulau Jawa.

Pendekatan penelitian kualitatif pada jurnal Ini adalah dengan metode studi kasus tentang adanya isu kelangkaan air pada tahun 2040 yang bersumber dari artikel yang dipublikasikan di salah satu laman website. 
Adanya dugaan tentang terjadinya kelangkaan air di pulau Jawa ditambah dengan hasil pengamatan dan pengalaman yang sering terjadi di beberapa daerah, maka dalam jurnal ini, studi kasus tersebut akan dilihat dari sudut pandang menjadi suatu fenomena.

\section{Pembahasan}

Pembahasan pada artikel ini diawali dari faktor penyebab isu kelangkaan air di Pulau Jawa. Pemerintah dalam kaitannya untuk mengetahui tentang kependudukan, membuat program yang bernama sensus penduduk. Sensus penduduk dilaksanakan sepuluh tahun sekali pada tahun yang berakhiran angka nol. Sensus penduduk dilaksanakan dengan metode tradisional yaitu dengan mendatangi rumah ke rumah. Sensus penduduk 2020 merupakan sensus yang ketujuh dilaksanakan sejak Indonesia merdeka. Namun pada saat sensus penduduk 2020 ini pendataan tidak dilakukan dengan mendatangi rumah ke rumah dikarenakan adanya pandemi.

Berdasarkan hasil sensus penduduk 2020 pada bulan September, jumlah penduduk di Indonesia mencapai 270,20 juta jiwa dimana bertambah 32,56 juta jiwa dibandingkan pada tahun 2010. Laju pertumbuhan penduduk per tahun (20102020) sebesar $1,25 \%$. Pulau Jawa menjadi salah satu pulau yang paling padat penduduknya di antara pulau-pulau yang lain disusul oleh pulau Sumatera. Pulau Jawa dengan konsentrasi penduduk terpadat sebesar 56,10\% dengan wilayah pulau Jawa hanya sebesar 7\% wilayah Indonesia. Pulau Jawa dihuni dengan jumlah penduduk sebesar 151,59 juta pada September 2020.

Mengingat pulau Jawa menjadi pusat kegiatan, tak heran apabila pulau Jawa menjadi pulau yang terbanyak penduduknya. Hampir dalam seluruh bidang kegiatan seperti ekonomi, pendidikan, politik, dan lain-lain berada pada pulau Jawa. Hal ini dikarenakan pembangunan ekonomi dan infrastruktur di pulau Jawa lebih cepat dibanding dengan lainnya dimana pusat pemerintahan Indonesia sendiri juga berada di pulau Jawa. Adanya kenaikan jumlah penduduk di pulau Jawa setiap tahunnya, akan memberikan dampak positif dan negatif.

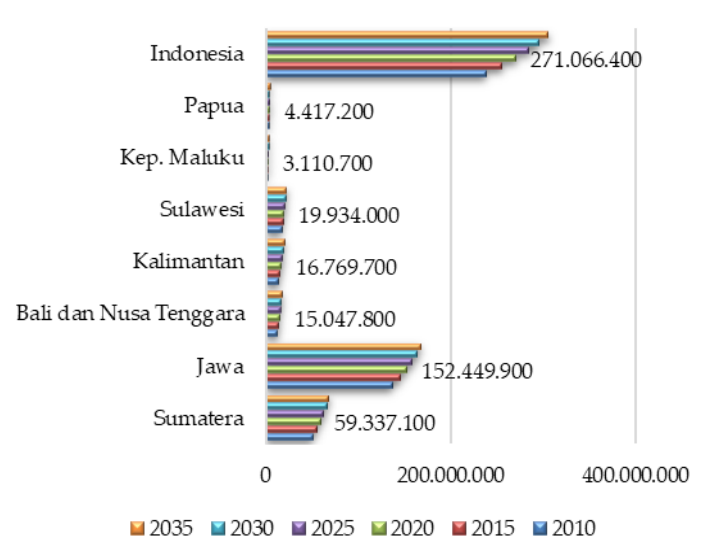

Sumber : Badan Pusat Statistik (2021)

Gambar 1

Data Proyeksi Penduduk di Indonesia pada Tahun 2010-2035

Dengan melihat data proyeksi penduduk Indonesia pada tahun 2010-2035, pulau Jawa selalu mengalami peningkatan jumlah penduduk. Rata-rata peningkatan penduduk di pulau Jawa setiap tahun sebesar \pm 6.058.460 juta jiwa. Perubahan jumlah penduduk ini disebabkan beberapa faktor yaitu kelahiran, kematian, dan migrasi. Pada tahun 2019, pulau Jawa khususnya DKI Jakarta menjadi provinsi ketiga yang memiliki penduduk migran (orang yang melakukan migrasi) sebesar 35,6\%. Migrasi tersebut terjadi karena adanya motif ekonomi. DKI Jakarta sendiri merupakan pusat pemerintahan dan ekonomi di Indonesia.

Jika pada tahun 2040 pulau Jawa masih menjadi primadona pusat kegiatan dengan pembangunan ekonomi dan infrastrukturnya yang lebih baik, maka dapat diperkirakan akan meningkatkan populasi jumlah penduduk seperti tahun-tahun sebelumnya. Hal ini akan memberikan dampak negatif bagi lingkungan pulau Jawa khususnya perubahan tata guna lahan. 
Semakin banyak penduduk yang menetap di suatu wilayah, lahan yang dimiliki wilayah tersebut akan banyak dipergunakan untuk pemukiman, pembangunan infrastruktur, dan lain sebagainya.

Dengan demikian, air yang seharusnya diserap oleh tanah dan menjadi cadangan air dalam tanah, hanya menjadi air lintasan karena lapisan tanah tidak bisa menyerap air. Hal ini akan berpengaruh terhadap ketersediaan air pada tahun-tahun selanjutnya. Jika pemerintah tidak mempersiapkan penanganan terkait masalah ini, maka tak heran jika pulau Jawa diisukan mengalami kelangkaan air pada tahun 2040.

Berdasarkan daftar kawasan Industri yang dipublikasikan oleh Kementerian Perindustrian Republik Indonesia, jumlah kawasan Industri di pulau Jawa sendiri sebanyak 65 kawasan industri. Semakin banyak industri yang beroperasi akan berpotensi dalam berbagai pencemaran akibat limbah industri, khususnya pencemaran air. Jika pencemaran air banyak terjadi, maka akan berpengaruh terhadap ketersediaan air bersih di pulau Jawa. Hal ini bisa menjadi salah satu faktor penyebab pulau Jawa diperkirakan akan mengalami kelangkaan air pada tahun 2040 apabila masalah-masalah diatas belum ada solusi untuk menyelesaikan. Terlepas dari faktor demografis, adanya faktor alam juga berpengaruh terhadap ketersediaan air yaitu adanya perubahan iklim. Indonesia adalah negara dengan iklim tropis dimana memiliki curah hujan yang tinggi. Namun dalam kondisi geologis tertenti dimana proses perjalanan air tanah memerlukan waktu yang cukup lama, sehingga apabila air diambil secara berlebihan maka akan mengakibatkan kelangkaan air. Wilayah hujan di Indonesia juga tidak merata seperti halnya di Pulau Jawa. Sebagin daerah di Pulau Jawa masih banyak yang diwaspadai akan hal kekeringan seperti di Kabupaten Cianjur dan Kabupaten Cirebon.

Setelah pembahasan proyeksi pertumbuhan penduduk dan potensi air.
Selanjutnya Kondisi Ketersediaan air di Pulau Jawa Di Indonesia Pulau Jawa menempati peringkat pertama penduduk terpadat. Tiap tahunnya pulau Jawa mengalami pertumbuhan penduduk, hampir setengah penduduk di Indonesia terdapat di Pulau Jawa. Pada tahun 2010 menurut data BPS penduduk jawa berjumlah 137.033.300 jiwa dan diperkirakan akan terus tumbuh secara signifikan pada tahun 2035. Dalam proyeksi penduduk Pulau Jawa di tahun 2035 mencapai 167.325.600 jiwa. Seiring dengan pertumbuhan penduduk di Pulau Jawa sendiri yang meningkat, pasti akan berdampak pada naiknya kebutuhan akan air khususnya air bersih. Iklim di tiap Provinsi yang ada di Pulau Jawa pun berbeda-beda. Kemarau yang sering dikaitkan dengan terjadinya krisis air. Sebagian besar warga Indonesia terdampak dalam krisis air bersih ini salah satunya adalah Miratin, seorang warga Desa Klepu, Pacitan Jawa timur mengalami kesulitan dalam hal sumber daya air bersih, Miratin sering membeli air dan juga sering mengambil air di dalam gua untuk digunakan sebagai kebutuhan seharihari karena air tersebut dianggap sebagai bersih, air yang diambil di goa tersebut selain bersih juga gratis untuk digunakan dalam memenuhi kebutuhan sehari-hari. Warga lain yang terdampak akan ketersediaan air bersih lainya yakni Mamas, warga Kecamatan Tambora, Jakarta Pusat. Dalam hal kebutuhan air bersih ia bergantung pada pedagang air keliling disaat musim kemarau tiba. Mamas menggunakan pompa air namun, pompa air manual miliknya semakin kepayahan menyedot air tanah dari sumur sedalam 14 meter. Miratin dan Mamas adalah salah satu dari sebagian besar warga Pulau Jawa yang masih belum bisa menikmati fasilitas PDAM. Kebutuhan penduduk akan air sangat di butuhkan, apalagi dengan meningkatnya penduduk, konsumsi akan air juga ikut meningkat. 


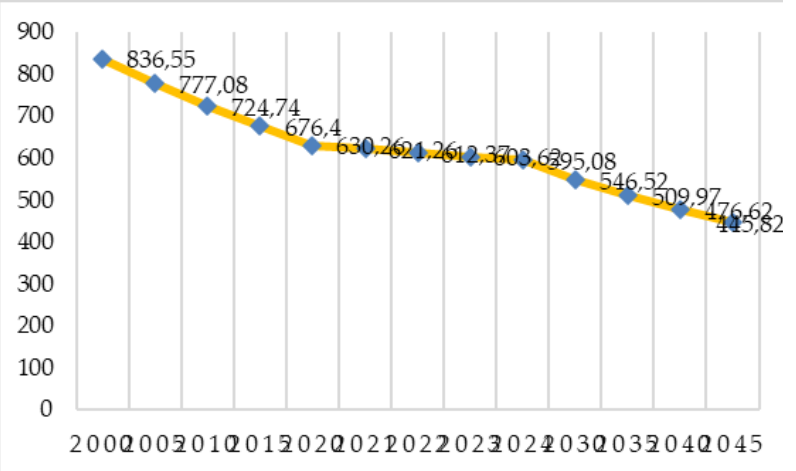

Sumber: Konsultasi Lingkungan Hidup Strategis Rencana Pembangunan Jangka Menengah Nasional (2019)

Gambar 2.

Proyeksi Ketersediaan Air pada Pulau di Indonesia Tahun 2000-2045 (m3/capita/year)

Jumlah ketersediaan air di tiap pulau yang ada di Indonesia (khususnya pulau Jawa) telah diproyeksikan yang sebelumnya dikaitkan dengan pertumbuhan penduduk di pulau Jawa yang semakin meningkat setiap tahunnya. Persediaan air di Jawa di proyeksikan akan menurun, karena banyak aktivitas dari rumah tangga maupun industri yang menggunakan air khusunya air bersih tersebut. Dari data tersebut dapat terlihat bahwa Pulau Jawa yang penduduknya hampir setengah dari Indonesia mengalami penurunan ketersediaan air yang sangat signifikan di tahun 2045. Di tahun 2000 hingga 2035 sudah digolongkan sebagai langka, dimana jumlah ketersediaan air dari debit 500-1000 sudah digolongkan sebagai kelangkaan air. Puncaknya yang paling parah penurunannya terjadi di tahun 2040 dan 2045 yang digolongkan sebagai kelangkaan absolut. Dalam kehidupan, kebutuhan air akan meningkat terus menerus, oleh karena itu dibutuhkan perkiraan kebutuhan air pada masa yang akan datang dan mempersiapkan ketersediaan air dalam jangka waktu panjang. Yang dimaksud dalam mempersiapkan untuk ketersediaan air dalam jangka panjang atau masa yang akan datang adalah mempersiapkan sarana prasarana yang dibutuhkan sesuai dengan peningkatan kebutuhan akan air bersih yang lebih ekonomis dan efisien. Untuk melihat seberapa besar air yang di butuhkan oleh penduduk jawa, maka harus melihat terlebih dahulu aktivitas apa saja yang di lakukan oleh penduduk di suatu wilayah tersebut, dengan mengetahui aktivitas yang di gunakan oleh penduduk maka akan terprediksi jumlah air yang tersedia untuk masa yang akan datang. Persediaan air tiap satu orang di Jawa mencapai $1.169 \mathrm{~m} 3 /$ tahun dan menurut kajian yang di lakukan pemerintah, pada tahun 2040 atau sampai 2045 nanti satu orang di pulau Jawa hanya mendapatkan persediaan air sebanyak 476 $\mathrm{m} 3$ / tahun per orang. Angka persediaan air bersih tersebut turun dengan drastis. Ancaman terjadinya krisis air ini lah yang menjadi kajian pemerintah dalam penanganan ketersediaan air.

\section{Pentingnya Air Bersih Bagi Masyarakat dan Kaitannya dalam Ekonomi}

Air adalah sumber daya yang sangat di butuhkan oleh mahkluk hidup, khususnya manusia. Manusia sangat memerlukan air untuk di konsumsi. Dalam keperluan minum untuk sehari-hari manusia membutuhkan 4 liter/hari atau setara dengan 16 gelas. Dengan mengkonsumsi air minum secara rutin akan memberikan efek yang menyehatkan bagi tubuh seseorang, seperti terhindar dari penyakit. Tanpa adanya air manusia akan mengalami dehidrasi dan akan cepat mengalami lemas pada tubuh di banding tanpa makanan. Kegunaan air selanjutnya digunakan untuk keperluan rumah tangga lainya seperti mandi dan mencuci. Untuk pemenuhan kebutuhan rumah tangga yang menggunakan air seperti digunakan dalam kebutuhan mandi dan mencuci, air tersebut harus mendapat standardiasi air bersih. Seperti air yang digunakan untuk minum, memasak, mandi dan mencuci, air tersebut adalah air yang bersih. Apabila air yang digunakan adalah air yang kotor disamakan dengan air yang di 
gunakan untuk pertanian maka manusia akan semakin rentan terkena penyakit seperti penyakit diare dan penyakit kulit.

Permasalahan akibat kurangnya ketersediaan air bersih dapat dilihat tentang kasus meninggalnya sejumlah balita yang di akibatkan oleh penyakit diare. Menurut Koordinator Komunikasi Kesehatan dan Kebersihan Environmental Service Program of USAID, Nona Utomo, Bandung hari Rabu, 100.000 balita di Indonesia meninggal dunia tiap tahunnya akibat serangan penyakit diare. Hal ini di akibatkan oleh lingkungan buruk yang terjadi di masyarakat. Angka kematian balita akibat diare di provinsi Jawa Barat lebih tinggi dibanding dengan angka nasional, yakni angka kematian balita 43 per 1000 kelahiran hidup. Dari masyarakat Jawa Barat sendiri banyak yang menggunakan air sungai dalam kebutuhan rumah tangga seperti minum, mencuci dan memasak. Dari sungai kotor tersebut terdapat bakteri e-coli yang mencapai 250 baku mutu. Dalam hal ini perlunya peran pemerintah dalam memberi edukasi untuk masyarakat agar merubah pola prilaku dalam mengkonsumsi air, air yang bersih untuk kesehatan dan terhindar dari penyakit diare maupun penyakit kulit.

Mengapa pemerintah perlu memberikan edukasi kepada masyarakat, sebab penyakit diare adalah penyakit yang berbahaya bagi kehidupan manusia, karena diare bisa menyebabkan hilangnya cairan tubuh pada anak dan orang dewasa yang dapat memicu kematian. Pentingnya air selain di gunakan untuk minum, memasak, mandi serta mencuci, air juga bisa digunakan untuk keperluan industri dan pertanian. Bagi petani, air adalah sumber daya pokok yang menunjang keberhasilan suatu kegiatan pertanian. Seperti halnya padi, untuk menumbuhkan padi maka akan dibutuhkan air, ketika air yang di gunakan dalam pemenuhan penanaman padi kurang, maka hal tersebut akan mengganggu tingkat produktivitas tanaman padi dan padi yang dihasilkan tidak maksimal. Dalam hal bertani, petani harus menjaga keseimbangan air. Terlau banyak air ataupun terlalu sedikit air yang digunakan untuk mengairi lahan pertanian akan berakibat buruk bagi tanaman seperti mengakibatkan tanaman tersebut mati.

Selanjutnya, air penting digunakan untuk kebutuhan di sektor industri. Dalam proses produksi air digunakan untuk pencucian. Yang dimaksud pencucian di sini adalah bagaimana semua alat atau mesin dan bahan-bahan yang akan digunakan harus dibersihkan atau di sterilkan terlebih dahulu dengan air. Selanjutnya air duganakan sebagai bahan produksi, seperti minuman. Dalam perindustrian air juga dapat menjadi pelarut limbah agar industri mejadi netral. Dalam hal kebutuhan rumah tangga, pertanian maupun industri dapat disimpulkan air berperan penting dalam keberlangsungan kehidupan.

Apabila sebuah wilayah mengalami kelangkaan air maka masyarakat wilayah tersebut akan mengalami kelaparan dikarenakan aktivitas pertanian salah satu bahan utamanya adalah air. Apabila ada suatu hambatan dalam persediaan air, maka para petani tidak bisa mengairi lahan sawahnya. Hal tersebut bisa memicu dampak negatif bagi kebutuhan pokok masyarakat khususnya berupa padi atau beras. Dampak lainya adalah hewan-hewan akan mati maka pasokan makanan akan terhenti. Adanya kelangkaan air tersebut menyebabkan kelaparan massal bagi manusia serta hewan yang hidup di wilayah tersebut apalagi bagi satwa-satwa yang dilindungi karena krisis kepunahannya.

Untuk mempertahankan operasional sekolah, rumah sakit, perindustrian, tempat makan maupun bisnis lainya membutuhkan air bersih dalam menjaga kebersihan dan kesehatan. Apabila terjadi kelangkaan maka semua sektor akan terganggu dan menghambat proses operasionalnya. Dan hal tersebut akan menyebabkan kerugian ekonomi yang begitu besar. 
Pemerintah melalui kebijakannya untuk menetapkan hukum sanksi yang tegas untuk sektor industri swasa maupun kalangan masyarakat bagi mereka yang membuang limbah industri ke sungai maupun perairan lainnya. Sebelum membuang limbah tersebut ke perairan maka harus diolah atau dinetralkan dahulu limbah tersebut. Dalam pembuangan sampah atau limbah rumah tangga pun masyarakat tidak boleh asal membuang sembarangan. Dengan adanya pengembangan teknologi dalam sanitasi air bersih dan memberikan penyuluhan air bersih sejak dini. Pentingnya menjaga air bersih serta menghemat air perlu ditanamkan saat anak belum menginjak dewasa atau masih kecil. Contohnya, seperti seorang guru yang terus-menerus mengingatkan muridnya untuk hal yang berkaitan dengan kebersihan, kesehatan serta peduli terhadap lingkungan sekitar. Dengan terlibatnya generasi muda dalam hal menjaga lingkungan sekitar, maka negara atau sebuah wilayah dapat mengantisipasi terjadinya kelangkaan air bersih.

\section{Kesimpulan}

Simpulan yang diperoleh dari serangkaian proses analisis data mulai dari awal pengumpulan data-data pendukung, penyusunan latar belakang, rumusan masalah sampai dengan hasil dan pembahasan jurnal yang dijelaskan dengan metode kualitatif deskriptif, diperoleh kesimpulan sebagai berikut :

Pertama, Air sebagai sumber penghidupan masyarakat Indonesia di berbagai bidang kehidupan, apalagi Indonesia dikenal sebagai negara maritim. Adanya isu tentang kelangkaan air melalui data proyeksi ketersediaan air di Indonesia dicocokkan dengan proyeksi data pertumbuhan penduduk di Indonesia. Khususnya di pulau Jawa yang paling padat penduduknya diantara penduduk dari pulaupulau yang lain. Karena sebagian besar penduduk di Indonesia lebih memilih untuk bermigrasi ke pulau Jawa dengan harapan merubah dan memperbaiki nasib untuk memperoleh kesejahteraan hidup yang lebih baik. Dengan adanya pertambahan jumlah penduduk yang bermukim di pulau Jawa, maka secara otomatis akan mengurangi tingkat persediaan air bersih dan meningkatnya jumlah konsumsi air. Tidak hanya konsumsi per orang, tetapi air juga menjadi pertimbangan dalam industriindustri yang ada di pulau Jawa yang terhitung terdapat 65 kawasan industri yang beroperasi dengan segala zat pencemar sehingga menimbulkan eksternalitas (pencemaran) air. Air yang tercemar sudah pasti akan mengurangi jumlah ketersediaan air bersih di pulau Jawa.

Kedua, Selain faktor manusia, berkurangnya ketersediaan air juga karena adanya faktor alam. Adanya faktor alam tersebut adalah karena faktor perubahan iklim. Iklim yang tidak menentu sering berpengaruh terhadap curah hujan yang rendah di beberapa daerah di Indonesia, khususnya di pulau Jawa.

Adapun selain simpulan, saran yang bersesuaian dengan latar belakang, rumusan masalah, tujuan, dan manfaat, metode penelitian serta hasil dan pembahasan. Maka saran yang dapat diberikan adalah semua stakeholders diharapkan sadar dan terus mengawasi ketersediaan air bersih dengan edukasi dan sosialisasi di berbagai level profesi dan tingkat pendidikan dalam rangka untuk memperoleh kemanfaatan air yang lebih berkelanjutan. Karena kelangkaan air bersih atau berkurangnya persediaan air bersih sudah pasti akan menghambat segala aktivitas penduduk, aktivitas industri dan aktivitas manusia bahkan aktivitas hewan dan tumbuhan. Adanya masalah kesehatan penduduk, masalah produktivitas sektor pertanian dan industri secara tidak langsung juga berdampak pada perekonomian Indonesia. Karena salah satu komponen pembangunan suatu negara adalah tingkat kesehatan penduduknya, maka jika penduduk pada suatu negara tersebut tidak 
sehat atau kualitas kesehatannya rendah, maka dapat dipastikan produktivitasnya rendah. Hal tersebut berdampak pada tingkat ekspor Indonesia juga akan berkurang, dan impor bertambah sehingga terjadi defisit anggaran. Utang Indonesia sudah pasti akan meningkat sebagai negara berkembang karena untuk biaya kesehatan penduduknya dibutuhkan anggaran yang cukup besar.

Isu kelangkaan air bersih pada tahun 2040 kemungkinan akan benar-benar terjadi apabila pulau Jawa masih dianggap sebagai pulau yang dikenal dengan pusat pembangunan ekonomi, infrastruktur dan tempat mengadu nasib. Maka akan terjadi lonjakan penduduk, maka tanah atau lahan yang seharusnya digunakan sebagai daerah resapan air akan berkurang karena dengan adanya pendirian pemukiman penduduk, infrastruktur yang menghilangkan fungsi air tanah.

\section{Daftar Pustaka}

Abdi, Moh Khoiri, and Novi Febriyanti. "Penyusunan Strategi Pemasaran Islam Dalam Berwirausaha Di Sektor Ekonomi Kreatif Pada Masa Pandemi Covid-19." El Qist - Journal of Islamic Economics and Business 10, no. 2 (2020): 160-79.

Amalia, Bunga, and Agung Sugiri. "Ketersediaan Air Bersih Dan Perubahan Iklim: Studi Krisis Air Di Kedungkarang Kabupaten Demak." Teknik Perencanaan Wilayah Kota 3, no. 2 (2014): 295-302.

Dewi, Lusiana, Ummi Hanik, Habibah Awwaliah, and Ana Toni Roby Candra Yudha. "Determinan Harga Dan Potensi Sampah Sebagai Sumber Modal Ekonomi Di Bank Sampah Syariah UINSA Surabaya." Nomicpedia 1, no. 1 (2021): 14-26.

Dewi, Ni Made Rai Christina Kusuma, and I Gusti Ayu Dewi Andayani. "Peran Mediasi Stres Kerja Pada Pengaruh Konflik Pekerjaan-Keluarga Terhadap Kepuasan Kerja Karyawan.” E-
Journal Managemen 9, no. Sumber Daya Manusia (2020): 2516-34.

Fatmawati, Ani, Ana Toni Roby Candra Yudha, and Hammis Syafaq. "Kontrak Kerja Dan Kesejahteraan ABK Nelayan Perspektif Etika Bisnis Islam Di Sarangmerduro, Jawa Tengah." Nukhbatul 'Ulum: Jurnal Bidang Kajian Islam 6, no. 2 (2020): 298-313.

Gusdini, Ninin, M. Januar J Purwanto, Kukuh Murtilaksono, and Kholil Kholil. "Kelangkaan Air Bersih: Telaah Sistem Pelayanan Penyediaan Air Bersih Di Kabupaten Bekasi." Jurnal Sumber Daya Air 12, no. 2 (2016): $175-86$. https://doi.org/10.32679/jsda.v12i2.6 4.

Habibi, M. Lutfillah, and Ana Toni Roby Candra Yudha. "Membangun Integrated Takaful Dan Wakaf Model Dalam Upaya Meningkatkan Kemanfaatan Pemegang Polis." AlUqud : Journal of Islamic Economics 1, no. 2 (2017): 139. https://doi.org/10.26740/jie.v1n2.p13 9-155.

Haryanti, Sri, Evi Gravitiani, and Mahendra Wijaya. "Studi Penerapan Bank Sampah Dalam Upaya Pengelolaan Lingkungan Hidup Di Kota Yogyakarta." Journal Bioeksperimen 6, no. 1 (2020): 60-68. https://doi.org/10.23917/bioeksperim en.v5i1.2795.

Indrawan, Imam Wahyudi, and Wahyuningsih Wahyuningsih. "Literature Review on REITs and Islamic REITs and Lessons Learned for Islamic REITs in Indonesia." International Journal of Islamic Economics and Finance (IJIEF) 2, no. 1 (2019): 21-46. https://doi.org/10.18196/ijief.2114.

Jocom, Hary, Daniel D Kameo, Intiyas Utami, and A. Ign. Kristijanto. "Air Dan Konflik: Studi Kasus Kabupaten Timor Tengah Selatan.” Jurnal Ilmu 
Lingkungan 14, no. 1 (2016): 51. https://doi.org/10.14710/jil.14.1.5161.

Nursafitri, Selly, and Ana Toni Roby Candra Yudha. "Instrumen Moneter Dan Belanja Daerah Serta Pengaruhnya Terhadap Penganggura Terbuka." Ekonomi Dan Bisnis 7, no. 2 (2020): 121-36. https://doi.org/10.35590/jeb.v6i2.164 9.

Othman, Baharudin, Sharifudin Md. Shaarani, and Arsiah Bahron. "The Influence of Knowledge, Attitude and Sensitivity to Government Policies in Halal Certification Process on Organizational Performance.” Journal of Islamic Marketing 8, no. 3 (2017): 393-408.

https://doi.org/10.1108/JIMA-092015-0067.

Puspayanthi, Ni Luh Putu Ayu Diah, Made Arie Wahyuni, and Made Aristia Prayudi. "Penguatan Pengelolaan Keuangan Desa Dan Optimalisasi Peran BUMDES Untuk Kemandirian Desa Pada Desa Di Kabupaten Jembrana." E-Jurnal S1 Ak Universitas Pendidikan Ganesha 1, no. 1 (2017).

Tangke, Paul Rizky Mayori. "Dampak Kegiatan Manusia Terhadap Perubahan Siklus Air Yang Memicu Kelangkaan Air Dunia," 2015.

Thomson Reuters and Dinar Standard. "State of the Global Islamic Economy Report 2019/20." Dubai International Financial Centre, 2018.

Wuyts, Wendy, Julie Marin, Jan Brusselaers, and Karl Vrancken. "Circular Economy as a COVID-19 Cure?" Resources, Conservation and Recycling 162, no. June (2020): 105016.

https://doi.org/10.1016/j.resconrec. 20 $\underline{20.105016 .}$.
Yalina, Nita, Akbar Pratama Kartika, and Ana Toni Roby Candra Yudha. "Impact Analysis of Digital Divide on Food Security and Poverty in Indonesiain 2015-2017." Jurnal Manajemen Teknologi 19, no. 2 (2020): $145-58$. https://doi.org/http://dx.doi.org/10.12 695/jmt.2020.19.2.3.

Yudha, Ana Toni Roby Candra, and Nyda Dusturiya. "Model Pengembangan Kewirausahaan Sosial Berbasis Mahasiswa Pada Lembaga Amil Zakat." El-Qist 8, no. 1 (2018): 161837.

Yudha, Ana Toni Roby Candra, Andaru Rahmaning Dias Prayitno, and Alfin Maulana. "Instrumen Moneter Indonesia : Penentuan Arah Kebijakan Serta Pengaruhnya Terhadap Pertumbuhan Ekonomi." Journals of Economics Development Issues ( JEDI ) 1, no. 2 (2018): 1-11. https://doi.org/https://doi.org/10.3300 5/jedi.v1i2.15.

Yudha, Ana Toni Roby Candra, Muhamad Nafik Hadi Ryandono, Akmalur Rijal, and Ida Wijayanti. "Financing Model to Develop Local Commodity Business of East Java in Maqashid Syariah Perspective." Test Engineering and Management 83, no. 3590 (2020): 3590-95.

Zustika, Anisa Fadilah, and Ana Toni Roby Candra Yudha. "Peer to Peer Lending System in Hifdul Maal Perspective: Evidence From He Fintech Company of Investree." Jurnal Ekonomi Syariah Teori Dan Terapan 7, no. 8 (2020): 1585-97.

https://doi.org/10.20473/vol7iss20208 pp1584-1597. 
